\title{
Model Komunikasi untuk Membangun Kapasitas Kewirausahaan dan Kesiapan Perubahan Pedagang Pasar Tradisional
}

\author{
Communication Model to Build Enterpreneurship Capacity \\ and Readiness for Changes among Traditional Market Traders
}

\author{
Akhmad Edhy Aruman ${ }^{1}$, Sumardjo ${ }^{2}$, Nurmala Katrina Pandjaitan ${ }^{2}$, Dwi Sadono ${ }^{2}$
}

${ }^{1}$ Sekolah Tinggi Ilmu Komunikasi LSPR Jakarta

${ }^{2}$ Departemen Sains Komunikasi dan Pengembangan Masyarakat, Fakultas Ekologi Manusia Institut Pertanian Bogor, Bogor

\begin{abstract}
Driven by the low entrepreneurial capacity and unpreparedness of traditional market traders facing competition with modern retailers, this study aims to formulate a communication model to build readiness for changes among traditional market traders. It used a survey to interview 559 traditional market traders using questionnaire. The study results were analyzed by Structural Equation Modelling (SEM) with LISREL tool and reinforced by in-depth interviews. The result shows that traders are in uncertainty facing revitalization. All elements (trader characteristics, message sources, messages, and participatory communications) have a positive impact on merchant readiness for revitalization with high entrepreneurship capacity. Therefore, to build the readiness of traders, it is the most important to build the traders' entrepreneurial capacity. A lack of success in building entrepreneurial capacity causes traders' unpreparedness to change. An appropriate communication model should involve the market operators/ authorities as a credible source of messages and information about the benefits and risks of revitalization, which will be effective if it develops merchant motivation to change and uses media that permit direct responses from communicators.
\end{abstract}

Keywords: entrepreneurship capacity, change readiness, participatory communication, traditional market traders

\begin{abstract}
Abstrak
Berangkat dari kondisi rendahnya kapasitas kewirausahaan dan ketidaksiapan pedagang pasar tradisional menghadapi persaingan dari peritel modern, penelitian ini bertujuan untuk merumuskan model komunikasi untuk membangun kesiapan perubahan pedagang pasar tradisional. Metode yang digunakan adalah survey dengan mewawancarai 559 pedagang pasar tradisional menggunakan instrumen kuesioner. Hasilnya dianalisis dengan menggunakan pendekatan kausalitas dengan alat bantu LISREL dan diperkuat dengan hasil dari wawancara mendalam. Hasil penelitian diperoleh gambaran bahwa dalam menghadapi revitalisasi, pedagang berada dalam situasi ketidakpastian. Seluruh unsur mulai dari karakteristik pedagang, sumber pesan, pesan, dan komunikasi partisipatif memberikan dampak positif terhadap kesiapan pedagang terkait dengan revitalisasi dengan kondisi kapasitas kewirausahaan pedagang tinggi. Karenanya, untuk membangun kesiapan pedagang, hal utama yang perlu dilakukan adalah membangun kapasitas kewirausahaan pedagang. Kekurangberhasilan membangun kapasitas kewirausahaan berdampak ketidaksiapan pedagang untuk berubah. Model komunikasi yang dinilai tepat adalah melibatkan pengelola pasar sebagai sumber pesan yang kredibel, dengan muatan pesan tentang manfaat dan risiko revitalisasi ternyata efektif bila melalui pengembangan motivasi pedagang untuk berubah, dan media yang memungkinkan terjadi tanggapan langsung dari pelaku komunikasi.
\end{abstract}

Kata kunci: Kapasitas Kewirausahaan, Kesiapan Perubahan, Komunikasi Partisipatif, Pedagang Pasar Tradisional

\section{Pendahuluan}

Rendahnyakapasitaskewirausahaanpedagang dan tidak memadainya kualitas fisik pasar tradisional merupakan masalah utama dalam pengembangan pasar tradisional. Tingkat keahlian dan ketrampilan dalam menjaga hubungan baik dengan pelanggan, tata letak dan kebersihan barang yang dijual yang rendah (Halim dan Ismaeni, 2007), dan kondisi pasar tradisional yang kurang memadai melemahkan kemampuan dan daya saing pedagang pasar tradisional.
Pada tahun 2007 Pemerintah Indonesia mengeluarkan kebijakan untuk meningkatkan kembali (revitalisasi) peran pasar tradisional. Ini ditunjukkan dengan adanya Peraturan Presiden nomor 112 tahun 2007 tentang Pengaturan dan Pengembangan Pasar Tradisional, Pusat Perbelanjaan, dan Toko Modern, yang bertujuan melindungi pasar tradisional (Santosa dan Indroyono, 2011). Melalui revitalisasi pasar tradisional yang semula kumuh, tidak aman, dan tidak nyaman diubah menjadi seperti pasar modern yang nyaman, bersih, dan rapi. 
Fenomena tersebut juga terjadi di Kota Bogor. Kondisi bangunan pasar tradisional yang tua, kumuh sekaligus penataan pedagang kakilima sehingga bisa mengurai kemacetan lalu lintas dijadikan alasan Pemerintah Kota Bogor bekerjasama dengan pengembang swasta membangun kembali beberapa pasar. Pada tahap awal paska PP Nomor 112, pada 2013 pemerintah Kota Bogor membangun kembali Pasar Gunung Batu dan Pasar Blok B Kebon Kembang. Langkah itu diikuti dengan pembagunan kembali Pasar Pasar Blok F yang bersebelahan dengan Pasar Blok B Kebon Kembang pada 2015.

Namun revitalisasipasartradisional tidakselalu berjalan mulus. Tarik menarik kepentingan masyarakat, pedagang, pemerintah kota dan pengembang swasta mengakibatkan tertundanya pelaksanaan revitalisasi tersebut. Pedagang berprasangka bahwa pemerintah memaksakan kehendaknya untuk kepentingan tertentu dan kurang memperhatikan aspirasi mereka. Pedagang menolak revitalisasi sehingga revitalisasi Pasar Blok F Kebon yang seharusnya berlangsung pada 2016 mengalami penundaan.

Adanya penolakan oleh pedagang terhadap rencana revitalisasi mengindikasikan rendahnya pelibatan pedagang dalam proses perencanaan revitalisasi. Pentingnya melibatkan masyarakat dalam pengambilan keputusan kebijakan telah lama diakui banyak ahli, sebab ada keyakinan bahwa partisipasi masyarakat dalam perdebatan publik dapat meningkatkan kualitas pengambilan kebijakan. Meskipun keterlibatan masyarakat diperlukakan hanya sebatas konsultasi atau "tokenisme" (Arnstein, 1969), praktik tersebut memungkinkan anggota masyarakat menyuarakan kebutuhan mereka dan didengar oleh lembaga. Menurut Mubyarto (1985), partisipasi merupakan kesadaran untuk membantu berhasilnya setiap program sesuai dengan kemampuan setiap orang tanpa berarti mengorbankan kepentingan diri sendiri.

Perencanaan kolaboratif ini memanfaatkan komunikasi sebagai dasar dalam proses berikutnya (rasionalitas komunikatif). Menurut Rogers (1976) peran komunikasi pembangunan berubah dari satu arah atau penyampaian pesan yang bersifat top-down, ke proses sosial dengan mengutamakan partisipasi, interaksi dua arah dan berbagi informasi. Dalam konteks inilah model komunikasi konvergen atau interaktif, menurut Sumardjo (1999), yang bersifat dua arah atau partisipatif baik vertikal maupun horizontal memungkinkan dihasilkannya keputusan di tingkat perencanaan program pembangunan yang memperhatikan kebutuhan dan kepentingan di tingkat "bawah."

Dari sudut peningkatan kapasitas seseorang atau kelompok, tujuan akhir dari komunikasi partisipatif adalah untuk mendemokratisasikan warga dan menyebabkan perubahan positif, efektif dan berkelanjutan dalam masyarakat. Dalam konteks pemberdayaan, Sumarti et al., (2017), memperkaya strategi pemberdayaan dengan menempatkan petani muda kopi sebagai subyek yang dinamis dalam membangun karakter kepemimpinan dan kewirausahaan.

Dalam komunikasi partisipatif masyarakat menjadi pelaku utama proses perubahan sosial, bukan penerima pasif dari keputusan yang dibuat oleh orang luar (Waisbord, 2008). Pendekatan komunikasi partisipatif memperhatikan pentingnya identitas budaya, aksi bersama dan dialog, pengetahuan lokal dan partisipasi pemangku kepentingan. Disini orang teberdayaan, ada saling pengertian, menciptakan kesadaran, berdialog, dan memulai berpartisipasi dan mobilisasi.

Munculnya penolakan juga menunjukkan ketidaksiapan pedagang untuk berubah. Teori kognitif sosialmenunjukkan bahwa orang cenderung melakukan perubahan ketika kesiapan untuk berubah tinggi (Bandura, 1986; Gist dan Mitchell, 1992). Kesiapan adalah aspek kognitif dari perilaku baik penolakan maupun dukungan terhadap upaya perubahan. Penolakan juga mencerminkan adanya kebuntuan dalam komunikasi antara pengelola dan pedagang. Untuk membangun kesiapan diperlukan komunikasi yang bisa melibatkan pihak-pihak terkait dengan perubahan (Armenakis dan Bedeian, 1999). Di bagian lain, pedagang pada dasarnya adalah wirausahawan. Wirausahawan selalu mencari perubahan - bukan menolak- meresponsnya dan memanfaatkannya sebagai sebuah peluang (Drucker, 1985).

Karenaitu,fenomenapenolakanmemunculkan pertanyaan tentang, pertama, pendekatan komunikasi yang dilakukan oleh pengelola pasar utuk membangun kesiapan pedagang dalam menghadapi revitalisasi. Kesiapan ditunjukkan oleh adanya keyakinan, sikap dan minat untuk ikut kegiatan revitalisasi (Armenakis et al., 1993). Kedua, karena tujuannya adalah meningkatkan kesejahteraan masyarakat, revitalisasi tidak hanya dilaksanakan dengan membangun atau memperbaiki fasilitas fisik, tetapi juga memperkuat 
sumberdaya manusia yang dalam hal ini adalah kapasitas kewirausahaan pedagang (Alfianita et al., 2015). Pertanyaannya adalah sejauhmana pengelola pasar membangun kapasitas kewirausahaan pedagang agar siap menghadapi revitalisasi pasar.

Berdasarkan uraian tersebut, tujuan dari penelitian ini adalah mendeskripsikan komunikasi partisipatif untuk membangun kewirausahaan dan kesiapan pedagang menghadapi revitalisasi; dan membuktikan apakah karakteristik pedagang, sumber pesan, terpaan pesan, komunikasi partisipatif dan dukungan lingkungan mempengaruhi kesiapan pedagang dalam revitalisasi pasar tradisional. Ketiga, menemukan model komunikasi yang dapat membangun kapasitas kewirausahaan dan kesiapan pedagang menghadapi revitalisasi.

\section{Metode Penelitian}

Penelitian ini dilakukan dengan pendekatan survey dan datanya dianalisis dengan pendekatan deskriptif dan inferensial. Pemilihan lokasi penelitian dilakukan secara sengaja (purposive) dengan mempertimbangkan bahwa objek dipilih karena menghadapi persoalan revitalisasi. Ada empat pasar yang diteliti, yakni Pasar Bogor, Pasar Gunung Batu, Pasar Blok B Kebon Kembang dan Pasar Blok F Kebon Kembang. Semua pasar tersebut adalah milik pemerintah kota. Waktu pelaksanaan penelitian Februari - September 2016.

Populasi dalam penelitian ini meliputi pedagang di empat pasar tadi yang besarnya sekitar 1510 pedagang. Jumlah sampel sebanyak 559 orang. Responden dipilih secara acak sebagai persyaratan uji statistic inferensial (Wijayanto, 2008). Skala pengukuran digunakan 1-3. Skala ordinal yang digunakan kemudian ditranformasi menjadi skala interval dengan metode successive interval (Muhidin, 2011). Uji normalitas dilakukan dengan menggunakan alat uji Kolmogorov-Smirnov Z.

Analisis data menggunakan, pertama, analisis deskriptif untuk memberikan gambaran tentang komunikasi yang dilakukan, dan menguji hubungan antar peubah menggunakan SEM melalui LISREL. Peubah dalam penelitian ini terdiri atas (1) Karakteristik pedagang, (2) Kredibilitas Sumber Pesan, (3) Terpaan Pesan Perubahan, (4) Komunikasi Partisipatif, (5) Dukungan Lingkungan, (6) Kualitas Komunikasi, (6) Kapasitas Kewirausahaan, dan (7) Kesiapan untuk
Berubah.

\section{Hasil dan Pembahasan}

\section{Karakteristik Pedagang}

Karakteristik pedagang adalah sifatsifat individu yang melekat pada pedagang dan berhubungan dengan aspek kehidupan. Pada Tabel 1 dapat dilihat sebagian besar umur responden berada pada kategori cukup tua (31-43 tahun). Dengan kondisi ini diharapkan mereka dapat memperoleh hasil lebih maksimal dibandingkan dengan mereka yang berumur tidak produktif. Ini karena kelompok umur cukup tua ini tergolong masih produktif dan umur mempengaruhi proses pengambilan keputusan.

Orang dewasa yang lebih tua harus menghadapi banyak situasi yang keputusannya memiliki konsekuensi keuangan. Karena itu, faktor umur dapat berpengaruh terhadap kesiapan individu untuk berubah. Stereotip pedagang yang lebih tua biasanya tidak menguntungkan, dan secara luas ada prasangka yang mengkaitkan antara penurunan produktivitas kerja dengan umur (Rhodes, 1983).

Pendidikan merupakan hal terpenting dalam hidup seseorang, dengan pendidikan, seseorang yang berusia produktif bisa berkompetisi dalam pasar kerja. Semakin tinggi tingkat pendidikan semakin banyak waktu yang disediakan untuk bekerja. Dengan semakin tinggi tingkat pendidikan, kecenderungan untuk bekerja semakin besar (Simanjuntak, 1985). Penelitian Sapar et al., (2006) juga menunjukkan hubungan nyata antara perilaku kewirausahaan pedagang kakilima, umur, pendidikan formal, pendidikan non formal, pengalaman berusaha dan motivasi.

Data penelitian juga menunjukkan bahwa sebagian besar pendidikan formal pedagang responden termasuk kategori sedang. Kondisi ini menggambarkan tingkat kemajuan dan kemampuan sumber daya yang relatif cukup tinggi. Dibandingkan dengan orang berpendidikan kurang, cenderung lebih mengembangkan perasaan kehilangan sesuatu dibandingkan mereka yang memiliki pendidikan lebih tinggi.

Mereka mengembangkan perasaan deprivasi relatif dengan membandingkan kondisi sosial ekonomi mereka saat ini dengan kelompok referensi mereka, yakni individu dengan tingkat pendidikan yang sama dari kelompok lainnya (Zang dan Hong, 
Tabel 1. Sebaran Responden berdasarkan Karakteristiknya $(n=559)$

\begin{tabular}{|c|c|c|c|}
\hline $\begin{array}{c}\text { Karakteristik } \\
\text { Pedagang }\end{array}$ & Parameter & $\begin{array}{c}\text { Frekuensi } \\
\text { (Orang) }\end{array}$ & Persentase \\
\hline \multirow{5}{*}{ Usia } & Muda $<31$ Tahun $;>17$ Tahun & 154 & 27.5 \\
\hline & Cukup Tua $=31-43$ tahun & 263 & 47.0 \\
\hline & Tua $>43$ Tahun & 142 & 25.4 \\
\hline & Rata-rata $=38,1$ tahun & & \\
\hline & Dasar $\leq$ Tamat Sekolah Dasar & 100 & 17.9 \\
\hline \multirow[t]{4}{*}{ Tingkat Pendidikan } & Menengah $=$ Tamat SMP-SMA & 405 & 72.5 \\
\hline & Tinggi $=$ Sarjana & 54 & 9.7 \\
\hline & Rendah $<4$ Tahun & 195 & 34.9 \\
\hline & Sedang 4-10 Tahun & 153 & 27.4 \\
\hline \multirow[t]{4}{*}{ Pengalaman Berdagang } & Tinggi $>10$ Tahun & 211 & 37.7 \\
\hline & Rata-rata $=9.4$ Tahun & & \\
\hline & Rendah $<8$ Jam & 200 & 35.8 \\
\hline & Sedang 8-10 Jam & 220 & 39.4 \\
\hline \multirow{2}{*}{ Curahan Waktu Berdagang } & Tinggi > $10 \mathrm{Jam}$ & 139 & 24.9 \\
\hline & Rata-rata $=8,9 \mathrm{Jam} /$ hari & & \\
\hline \multirow[t]{6}{*}{ Kekosmopolitan } & Rendah $=$ Interaksi dengan 1-3 Media & 168 & 30.1 \\
\hline & Sedang $=$ Interaksi dengan 4-6 Media & 227 & 40.6 \\
\hline & Tinggi $>6$ Media & 164 & 29.3 \\
\hline & Rata-rata $=5$ Media & & \\
\hline & Kecil $<$ Rp 8 Juta & 129 & 23.1 \\
\hline & Besar Rp 8 - Rp 40 Juta & 245 & 43.8 \\
\hline \multirow[t]{4}{*}{ Modal } & Sangat Besar $>$ Rp 40 Juta & 185 & 33.1 \\
\hline & Rata-rata $=$ Rp 14 Juta & & \\
\hline & Rendah $<$ Rp 1 Juta per hari & 135 & 24.2 \\
\hline & Sedang $=\operatorname{Rp} 1,1-5$ Juta per hari & 289 & 51.7 \\
\hline \multirow[t]{4}{*}{ Omset } & Tinggi $>$ Rp 5 juta per hari & 135 & 24.2 \\
\hline & Rata-rata $=\mathrm{Rp} 3,5$ Juta per hari & & \\
\hline & Rendah $<$ Rp 0.3 Juta per hari & 168 & 30.1 \\
\hline & Sedang $=$ Rp 0.4 Juta - Rp 1 Juta & 227 & 40.6 \\
\hline \multirow{2}{*}{ Keuntungan } & Tinggi $>$ Rp 1 Juta & 164 & 29.3 \\
\hline & Rata-rata $=\mathrm{Rp} 0.9$ Juta & & \\
\hline
\end{tabular}

2013). Deprivasi relatif adalah keadaan psikologis yang menunjukkan ketidakpuasan seseorang atas kesenjangan atau kekurangan subjektif yang dirasakannya pada saat keadaan diri dan kelompoknya dibandingkan dengan orang atau kelompok lain. Keadaan deprivasi bisa menimbulkan persepsi adanya suatu ketidakadilan.

Pengalaman berdagang memberikan penambahan keahlian dalam menjalankan usaha secara independen serta kemampuan untuk mengukur kualitas informasi sehingga dapat menambah pemahaman tentang manfaat nyata dari adanya peluang baru, mempercepat penciptaan bisnis proses, dan meningkatkan kinerja (Cooper et al., 1995). Pengalaman juga bisa meningkatkan keyakinan dalam kemampuan wiraswastawan untuk berhasil. Ini berarti bisa memperkuat niat seseorang untuk masuk ke peluang baru (Wright et al., 1997).

Temuan dalam penelitian ini menunjukkan bahwa pedagang yang memiliki pengalaman 
berdagang tinggi atau lebih dari 10 tahun berdagang di pasar persentasenya paling tinggi. Hal ini menunjukkan bahwa para pedagang pasar umumnya adalah memiliki pengalaman berdagang yang pada akhirnya memberikan proses pendidikan yang cukup memadai untuk menjalankan usaha.

\section{Revitalisasi Pasar Sebagai Usaha Pemberdayaan Pedagang}

Secara umum revitalisasi dimaknai sebagai proses dan cara menghidupkan kembali suatu kawasan yang tidak berfungsi dengan baik. Revitalisasi dilakukan dengan meningkatkan vitalitas kawasan lama sehingga mampu menciptakan kawasan publik yang berkualitas dan meningkatkan pertumbuhan ekonomi masyarakat di sekitar kawasan revitalisasi. Dalam perspektif pengelola pasar, revitalisasi pasar merupakan alternative untuk meningkatkan keberdayaan pedagang karena kondisi pasar nyaman, bersih, aman, dan teratur, pengunjung pasar meningkat sehingga omset pedagang juga naik. Bila omset pedagang naik, keuntungan yang didapat pedagang naik dan kesejahteraan pedagangpun meningkat.

Hasil penelitian ini (Tabel 2) menunjukkan perbedaan kinerja kios di pasaryang belum direvitalisasi dan sudah direvitalisasi. Secara keseluruhan, terdapat kenaikan jumlah pengunjung, pembeli dan penjualan baik di pasar yang belum dan sudah direvitalisasi. Namun terdapat perbedaan tingkat kenaikan jumlah pengunjung, pembeli dan penjualan. Pasar yang direvitalisasi menunjukkan kenaikan yang lebih rendah dibandingkan kenaikan jumlah pengunjung pasar yang belum direvitalisasi. Hanya saja, perbedaan tersebut tidak signikan.

Untuk kenaikan jumlah pembeli, kenaikan jumlah pembeli pada kios di pasar yang sudah direvitalisasi lebih tinggi daripada yang belum direvitalisasi. Perbedaan tersebut berdasarkan uji tyang dilakukan pada taraf 5\% hasilnya signifikan. Hal ini menunjukkan bahwa revitalisasi telah meningkatkan jumlah pembeli di pasar. Namun kenaikan jumlah pembeli tidak secara signikan menaikkan penjualan. Kenaikan penjualan barang di kios pedagang pasar yang direvitalisasi lebih tinggi daripada kios pasar yang belum direvitalisasi, namun perbedaan tersebut tidak signinifikan.

Fenomena tersebut memberikan gambaran bahwa revitalisasi pasar tidak terlalu meningkatkan kinerja kios pedagang menjadi lebih baik. Hal ini sejalan dengan hasil penelitian Prastyawan et al., (2015) yang menunjukkan bahwa revitalisasi Pasar Wonokromo yang dilakukan Pemkot Surabaya dan PD Pasar Surya terkesan tidak sesuai dengan kepentingan para pedagang karena tidak membuat mereka menjadi lebih baik.

Pasar Blok F merupakan blok terakhir Pasar Kebon Kembang yang harus disempurnakan dan diperbaiki untuk menunjang blok yang lain. Ada tiga alasan utama revitalisasi Blok F Pasar Kebon Kembang; Pertama, Pasar Kebon Kembang merupakan kawasan ekonomi. Jadi bukan sekadar pasar. Beberapa lokasi penting di kawasan ini seperti Masjid Agung dan Taman Topi direvitalisasi dan ditata kembali. Kedua, umur Pasar Blok F sudah 21 tahun sehingga dari segi struktur dan kekuatan bahan mendesak untuk diperbaiki. Ketiga, kawasan Kebon Kembang perlu penataan mengingat belum tersedianya tempat parkir kendaraan roda empat secara memadai akibatnya banyak pedagang yang kerepotan karena lokasi bongkar muat barang yang jauh dari pasar.

Namun, persepsi bahwa revitalisasi tidak mengubah kinerja membuat pedagang sejak awal berkeberatan dengan rencana pengelola pasar yang mengubah total bangunan pasar. Dalam pandangan

Tabel 2. Perbedaan Kinerja Kios Pedagang Sebelum dan Sesudah Revitalisasi Pasar

\section{Rata-rata Kenaikan}

\begin{tabular}{lcccccc}
\multicolumn{1}{c}{ Item Kenaikan } & Total & \multicolumn{2}{c}{ Sebelum Revitalisasi } & \multicolumn{2}{c}{ Sesudah Revitalisasi } & \\
& $(\mathbf{n = 5 5 9 )}$ & $\mathbf{( n = 1 4 1 )}$ & Std. Dev & $\mathbf{( n = 4 1 8 )}$ & $\mathbf{. S t d . ~ D e v}$ & .t Sign \\
\hline Pengunjung & $29.39 \%$ & $16.85 \%$ & 0.22 & $16.78 \%$ & 1.02 & 0.99 \\
Pembeli & $22.68 \%$ & $13.84 \%$ & 0.20 & $18.39 \%$ & 0.24 & 0.03 \\
Penjualan & $21.70 \%$ & $13.09 \%$ & 0.21 & $17.10 \%$ & 0.23 & 0.06 \\
\hline
\end{tabular}


mereka, bila pasar diubah total akan ada pengaturan dan penataan ulang tempat untuk berdagang. Pedagang juga menolak revitalisasi karena berdampak buruk bagi pedagang. Menurut Hasyim, pedagang kios di Blok 6, revitalisasi tidak mendukung ekonomi pedagang. "Dulu, sebelum revitalisasi (Blok 2, pen), saya punya 21 kios. Sekarang hanya tinggal 2 kios, karena harganya semakin mahal dan saya tidak siap direvitalisasi," katanya.

Perubahan tata letak kios pasar setelah direvitalisasi membuat pedagang khawatir tentang masa depannya karena masuk dalam situasi baru. Pedagang yang semula berada di lokasi strategis, belum tentu mendapatkan lokasi yang sama dengan yang ditempati saat sebelum revitalisasi. Pedagang yang semula memiliki kios di depan, mempunyai peluang juga untuk mendapat kios yang berada di posisi di dalam. Bagi pedagang, lokasi di depan atau belakang merupakan hal yang utama karena dinilai strategis. Lokasi tempat untuk berdagang sangat berpengaruh besar terhadap pendapatan, karena tempat atau lokasi yang strategis untuk berjualan mudah dijangkau oleh para pembeli. Hal terebut cukup beralasan. Hal ini selaras Tarigan (2005) bahwa dalam kegiatan ekonomi alokasi geografis dari sumber-sumber yang potensial, serta hubungannya dengan atau pengaruhnya terhadap keberadaan berbagai macam kegiatan lain baik ekonomi maupun sosial.

Karenanya, rencana revitalisasi, pertama, membuat pedagang merasa cemas apakah perubahan lokasi tersebut juga berpengaruh terhadap pendapatannya selama ini. Kedua adalah selama masa pembangunan pasar, ada relokasi. Situasi ini, berdasarkan hasil wawancara dengan pedagang, juga membuat pedagang repot dan khawatir pendapatannya berkurang karena pembeli yang merasa terganggu oleh kegiatan selama masa pembagunan tersebut.

\section{Komunikasi Partisipatif Pengelola dan Pedagang Pasar}

Revitalisisasi Pasar di Bogor digulirkan Pemerintah Kota Bogor awal 2015. Diseminasi rencana revitalisasi dilakukan melalui saluran media berupa selebaran, papan pengumuman dan spanduk di masing-masing pasar. Spanduk ditempatkan di depan pasar. Hampir semua pedagang mengetahui rencana revitalisasi pasar, meski pengumuman itu hanya ada di depan kantor pengelola.
Selebaran, papan pengumuman dan spanduk merupakan saluran media yang seringkali menjadi cara yang paling cepat dan efisien untuk menginformasikan ke audiens pengadopsi potensial tentang keberadaan suatu yang baru. Penelitian yang dilakukan McDivitt et al., (1997) menunjukkan bahwa paparan pesan kampanye melalui media masa meningkatkan pengetahuan tentang kesehatan di Filipina. Pada kampanye tentang program vaksinasi di Filipina, kontak dengan atau informasi melalui saluran antarpribadi tidak berkontribusi terhadap perubahan pengetahuan tentang program vaksinasi (McDivitt et al., 1997). Sedangkan dialog tatap muka antara individu, efektif untuk membujuk orang untuk menerima ide baru (Rogers, 2003).

Selain selebaran, papan pengumuman dan spanduk, pengelola pasar mengadakan setidaknya tiga kali dialog dengan pedagang. Dialog dengan pedagang terdiri dari dua kelompok. Kelompok pertama adalah dialog dengan para direksi perusahaan pengelola pasar. Kedua secara informal atau dialog dengan penanggungjawab masing-masing unit pengelola pasar. Dialog dengan direksi dilakukan secara terjadwal dan terencana, selain melibatkan pedagang secara perorangan, melibatkan pula organisasi pedagang. Sedangkan dialog informal dilakukan tanpa rencana. Dialog ini biasanya terjadi kapanpun bila keduanya bertemu seperti saat pengelola pasar di tingkat unit menarik dan mengumpulkan iuran pasar bulanan dan sebagainya. Di antara pedagang juga terjadi dialog sehingga informasi tentang revitalisasi sampai ke pedagang yang kebetulan tidak bisa hadir dalam dalam dialog formal.

Hasil penelitian menunjukan rendahnya keterlibatan partisipan komunikasi selama proses perencanaan revitalisasi. Hampir semua dimensi komunikasi partisipatif skornya rendah. Skor terendah dimensi komunikasi partisipatif ada pada tingkat umpan balik dan rasa saling percaya antara pengelola dan pedagang pasar. Dalam dialog, pengelola pasar mendapatkan umpan balik dari pedagang. Namun beberapa masukan dari pedagang, menurut pedagang, kurang diperhatikan. Misalnya, usulan pedagang agar nantinya setelah pasar direvitalisasi bisa menempati kios seperti sebelum revitalisasi ditolak pengelola. Demikian pula soal usulan agar pengelola tidak menaikkan tarif retribusi karena tarif tersebut tidak seimbang dengan keadaan pasar yang sepi. “....Pengelola pasar tidak menerima usulan tersebut. 
Tarif retribusi tetap naik," kata Juju.

Dalam setiap pertemuan, pedagang menanyakan alasan revitalisasi pasar. Pengelola pasar mengatakan bahwa revitalisasi pasar dilakukan agar pasar lebih ramai, nyaman, dan rapih. Karena itu, pedagang melihat bahwa pengelola mempunyai niat yang tulus. Namun demikian, pedagang menilai pengelola belum terbuka dan memberikan informasi yang lengkap. Misalnya, dalam acara sosialisasi digambarkan tentang dampak dampak positif revitalisasi. Namun pengelola tidak menunjukkan dampak negatif setelah pasar direvitalisasi. Misalnya soal kemungkinan penurunan penjualan bila pasar direvitalisasi.

Pedagang beranggapan bahwa revitalisasi membuat pasar menjadi sepi pengunjung. Anggapan ini muncul dari pengalaman revitalisasi pasar Gunung Batu Bogor, 2014 lalu. Setelah revitalisasi masyarakat enggan berbelanja di Pasar Gunung Batu Bogor. Ada persepsi jika pasar direvitalisasi harga barang naik. Apalagi seperti yang terjadi di Pasar Gunung Batu Bogor yang menempatkan los sayuran dan sebagainya di lantai dua. "Pembeli enggan berkunjung ke pasar baru (revitalisasi) karena bila berbelanja untuk kebutuhan sehari-hari harus naik ke lantai dua. Sebelum direvitalisasi, penjual bahan pangan dan kebutuhan sehari-hari lainnya ada di lantai dasar sehingga pembeli mudah menjangkaunya," kata seorang pedagang pasar Gunung Batu.

Hasil penelitian menunjukkan rendahnya rasa saling percaya antara pengelola dan pedagang.
Rendahnya rasa saling percaya antara pengelola dan pedagang disebabkan oleh pengalaman pedagang. Di mata pedagang, pengelola pasar sering ingkar janji. Pengalaman ini membuat pedagang "mencurigai" pengelola mempunyai agenda tersendiri. Salah satu masalah adalah soal pembagian kios. Seperti yang terjadi pada revitalisasi pasar sebelumnya, untuk pembagian kios, kesepakatannya adalah diundi, namun seperti yang disampaikan pedagang pada saat wawancara, dalam perjalanan dijumpai transaksi di luar yang disepakati. “..... prakteknya, bisa ada pendekatan-pendekatan untuk kita dapet tempat kita lagi," kata Tantra, pedagang.

Selain rasa saling percaya yang rendah, tingkat keterbukaan masing-masing pelaku komunikasi juga rendah. Padahal keterbukaan merupakan salah faktor yang dapat meningkatkan kepercayaan. Sejumlah penelitian mendukung pandangan ini. Butler (1991); Senjaya dan Pekerti (2010) menemukan bahwa manajer yang secara terbuka bertukar ide dengan karyawan dapat meningkatkan rasa saling percaya diantara mereka.

\section{Kapasitas Kewirausahaan}

Hasil penelitian menunjukkan bahwa kapasitas kewirausahaan pedagang pasar tradisional secara keseluruhan memiliki kecenderungan yang sedang. Hasil pengujian korelasi (Tabel 3) menunjukan bahwa beberapa karakteristik pedagang mempunyai hubungan dengan dimensi yang mendukung kapasitas

Tabel 3. Hubungan antara Karakteristik Pedagang dan Dimensi Kapasitas Kewirausahaan

\begin{tabular}{llcccc}
\hline \multirow{2}{*}{ No. Karakteristik Pedagang } & \multicolumn{3}{c}{ Dimensi Kapasitas Kewirausahaan } \\
\cline { 3 - 5 } & $\begin{array}{c}\text { Wawasan } \\
\text { Bisnis }\end{array}$ & $\begin{array}{c}\text { Keberanian } \\
\text { Berisiko }\end{array}$ & $\begin{array}{c}\text { Tanggap } \\
\text { terhadap Peluang }\end{array}$ & Self-Efficacy \\
\hline 1 & Umur & $-0,099^{*}$ & $-0,189^{* *}$ & $-0,143^{* *}$ & $-0,032$ \\
2 & Tingkat Pendidikan & $0,088^{*}$ & $0,098^{*}$ & 0,067 & $-0,059$ \\
3 & Pengalaman Berdagang & $-0,082$ & $-0,150^{* *}$ & $-0,160^{* *}$ & $-0,081$ \\
4 & Curahan Waktu Berdagang & $0,111^{* *}$ & $0,205^{* *}$ & $0,127^{* *}$ & 0,043 \\
5 & Kekosmopolitan & $0,130^{* *}$ & $0,227^{* *}$ & $0,135^{* *}$ & $-0,015$ \\
6 & Modal Usaha & $0,180^{* *}$ & $0,220^{* *}$ & $0,136^{* *}$ & 0,056 \\
7 & Omset & $0,111^{* *}$ & $0,205^{* *}$ & $0,127^{* *}$ & 0,043 \\
8 & Tingkat Keuntungan & 0,077 & $0,155^{* *}$ & 0,076 & $-0,014$ \\
\hline
\end{tabular}

Keterangan: ** Signifikan pada $0,01,{ }^{*}$ Signifikan pada 0,05 
kewirausahaan seperti wawasan bisnis, keberanian mengambil risiko, dan tanggap terhadap peluang. Bila dilihat dari korelasi yang positif, maka rendahnya kapasitas kewirausahaan tersebut disebabkan oleh rendahnya curahan waktu, tingkat kosmopolitan pedagang, modal dan omset pedagang. Hasil penelitian Zainura et al., (2016) juga menunjukan bahwa perilaku kewirausahaan dipengaruhi oleh karakteristik individu seperti tingkat pendidikan, pengalaman yang cukup, dan modal.

Namun hasil penelitian ini menunjukkan bahwa usia berkorelasi negatif dengan keberanian untuk menanggung risiko dan tanggap teradap peluang. Ini berarti semakin tinggi usia pedagang, semakin enggan untuk menanggung risiko seperti kerugian dan semakin tidak tanggap terhadap terhadap peluang. Hal ini selaras dengan temuan Xiao et al., (2001), Jianakoplos dan Bernasek (1998) bahwa terdapat korelasi negatif antara umur dan keberanian dalam mengambil risiko.

Wirausahawan muda, menurut Xiao et al., (2001) cenderung memiliki keinginan yang kuat untuk mewujudkan jati diri mereka sendiri dan mencapai prestasi melalui kegiatan kewirausahaan, seperti berinvestasi di pasar baru, dan meluncurkan produk baru. Hal ini juga memberi gambaran bahwa pedagang yang lebih senior atau memiliki pengalaman berdagang yang tinggi cenderung lebih berhati-hati karena pelajaran yang dipetik dari praktik-praktik mereka sebelumnya. Hal ini sekaligus menjelaskan bahwa pengalaman berdagang mempunyai korelasi negatif terhadap keberanian dalam mengambil risiko.

Sebaran pengalaman pedagang yang menunjukkan bahwa pedagang yang memiliki pengalaman lebih dari 10 tahun persentasenya tertinggi memberikan gambaran bahwa pengalaman mereka dalam berdagang relatif lama. Pengalaman berusaha yang lama memberikan proses pendidikan yang cukup memadai untuk menjalankan usaha. Namun di sisi lain, pengalaman ini membuat pedagang kurang berani dalam mengambil risiko.

Berdasarkan wawancara yang dilakukan, pedagang lebih banyak mengandalkan pengalaman dan jarang mengikuti pelatihan tentang bisnis. Hal ini mencerminkan kepasifan pedagang dalam upaya meningkatkan kapasitas kewirausahaanya. Tingkat keinginan pedagang untuk bertanya kepada orang yang dianggap bisa meningkatkannya kinerja usahanya rendah. Demikian pula kemauan untuk mencari informasi melalui media masa juga rendah. Kondisi kekurangan informasi ini dikhawatirkan bisa berdampak pada kurangnya kemampuan pedagang menganalisis situasi di sekitarnya.

Kapasitas kewirausahaan adalah suatu bentuk modal manusia (human capital) yang bergantung pada tingkat pendidikan, pelatihan, pengalaman, dan kesehatan (Klein dan Cook, 2006). Hasil penelitian menunjukkan bahwa rata-rata pendidikan formal responden adalah 8 tahun (setara SMP kelas II). Hal ini mencerminkan relatif rendahnya human capital para pedagang. Padahal, pendidikan merupakan investasi yang dapat memberikan keuntungan melalui produktivitas kerja.

Seseorang dikatakan memiliki wawasan bisnis bila memiliki kemampuan menganalisis dan mengevaluasi perubahan lingkungan bisnis, kekuatan dan kelemahan yang ada pada dirinya. Kemampuan ini mempengaruhi keberhasilan bisnis seseorang (Nastase dan Stoica, 2010). Wawasan bisnis yang rendah menyebabkan pedagang khawatir dengan perubahan termasuk masuknya pesaing baru di lingkungan mereka. Ketidakmampuan mereka mengintegrasikan informasi karena kurangnya informasi membuat mereka tidak bisa secara cepat bereaksi dan lemah memprediksi perubahan dalam lingkungan bisnis (Morgen, 2010). Karena itu mereka merasa khawatir terhadap kondisi masa depannya.

Rendahnya tingkat pendidikan membuat pedagang lemah dalam membangun keunggulan bersaing melalui penurunan biaya (Becker dan Gerhard, 1996), mengubah kinerja dan berkencenderungan mempertahankan nilai-nilai tradisional (Vaizey, 1992). Banyak praktek berdagang tradisional yang masih dilakukakan pedagang. Salah satu praktik tradisional yang tidak berubah di kalangan pedagang adalah dalam hal penggunaan laba. Mereka sering menggunakan hasil penjualan termasuk laba yang diperoleh hari itu untuk keperluan pribadi seperti membeli makanan dan minuman atau keperluan sehari-hari lainnya. Idealnya, untuk belanja keperluan pribadi pedagang seharu-hari diambil dari sebagian laba yang mereka sisihkan pada waktu sebelumnya.

Selain melalui pendidikan sekolah, produktivitas bisa ditingkatkan melalui pendidikan keterampilan luar sekolah, pengalaman, dan motivasi kerja. Hasil penelitian ini juga menunjukkan kurangnya pedagang menambah ketrampilan berdagang melalui pelatihan. Sebanyak $62.4 \%$ pedagang responden 
tidak pernah mengikuti kursus/pelatihan tentang kewirausahaan atau yang berhubungan dengan pekerjaan mereka. Artinya, pendidikan non formal responden termasuk kategori rendah. Hal ini sekaligus memberikan gambaran bahwa dalam menjalankan usahanya, sebagian besar dari pedagang berdasarkan pada pengalaman.

Ada perdebatan tentang proses pembelajaran kewirausahaan. Rae (2006) mendefinisikan pembelajaran kewirausahaan sebagai "suatu proses dinamis yang muncul dari kesadaran, refleksi, asosiasi dan aplikasi yang melibatkan transformasi pengalaman dan pengetahuan ke dalam hasil belajar fungsional." Pembelajaran kewirausahaan seseorang terjadi melalui proses pengalaman menantang yang dialaminya secara berbeda, seperti mengenali peluang, mengatasi masalah, dan melakukan peran yang berbeda dari seorang pengusaha (Politis, 2005).

Pengalaman pribadi atau pengalaman dalam proses pembelajaran kewirausahaan dianjurkan oleh Henry et al., (2005) sebagai cara untuk belajar kewirausahaan. Smith et al., (2006) menyarankan pembelajaran melalui pengalaman. Disini seseorang memperoleh pengetahuan dan keterampilan yang diperlukan untuk dapat menghadapi tantangan dan mengatasi masalah seputar perusahaan mereka.

Pengalaman, menurut Zhao et al., (2005) mengembangkan kepercayaan kewirausahaan dan keinginan untuk berhasil melakukan peran dan tugasnya sebagai seorang pengusaha. McGrath dan MacMillan (2000) menyatakan bahwa pola pikir kewirausahaan yang memungkinkan dan mendorong individu untuk menemukan peluang dapat dikembangkan melalui pengalaman daripada metode pendidikan kewirausahaan tradisional.

Penelitian Putta (2014) menunjukkan ketrampilan manajemen pengusaha yang mengikuti program pelatihan manajemen kewirausahaan cenderung meningkat. Berdasarkan temuan itu, Putta (2014) menyarankan agar usaha yang dimiliki wirausahawan berhasil mencapai tujuan dan sasaran, wirausahawan perlu mendapatkan pelatihan kewirausahaan sesuai dengan kebutuhan mereka. Karena itu, untuk meningkatkan ketrampilan kewirausahaan yang tercermin pada tingkat efisiensi dalam pengambilan keputusan dan keberhasilan perusahaan secara berkesinambungan, diperukan pelatihan yang baik.

Namun, masalah ini tidak mendapat perhatian serius dari pengelola pasar maupun pemerintah kota. Hasil penelitian menunjukkan lemahnya dukungan lingkungan pedagang (skor 35.20). Hal ini mencerminkan persepsi pedagang bahwa pengelola pasar kurang membantu mereka dalam meningkatkan kapasitas kewirausahaan mereka. Dari data kapasitas kewirausahaan tercermin kurangnya pelatihan kewirausahaan yang diharapkan pedagang oleh pengelola pasar. Pengelola pasar pernah melakukan pembinaan misalnya dalam hal kewirausahaan ke pedagang pasar, namun tidak terlalu spesifik. Pengelola hanya menjelaskan bahwa pedagang harus melayani konsumen dengan baik. Pengelola pasar juga beberapa kali mengadakan seminar bagi para pedagang yang dilakukan selama 2 sampai 3 jam pada pagi hari di lahan parkir dengan tenda.

Seminar diadakan pengelola sebanyak empat sampailimakalidalamsetahun.Pesertanyajugaterbatas. Artinya tidak semua pedagang diberi kesempatan untuk mengikuti acara, termasuk pelatihan manajemen keuangan kepada pedagang. "Pelatihan memang tidak bisa semua pedagang, pasti hanya perwakilan. Perwakilan inilah yg diharapkan menularkan ilmunya kepada pedagang lain," kata Dirut PD Pasar Pakuan Jaya Andri A Mansyur. Namun beberapa pedagang mengaku belum pernah mengetahui pelatihan yang diadakan oleh PD PPJ. "Dulu iya.. Namun sekarang saya kok belum pernah dengar," kata Raffi, 42 tahun, Pedagang Kios Pasar Blok B.

Program peningkatan kapasitas melalui pelatihan seperti mengenai sistem pembukuan, serta adanya pembinaan yang berkaitan dengan manajemen pemasaran seperti mengubah mindset serta penampilan pedagang dan sebagainya, menurut pengakuan pedagang belum pernah dilakukan. Dalam berdagang, pedagang umumnya belajar dari pengalaman dan tidak mendapatkan pengetahuan atau ketrampilan dari pengelola pasar, setidaknya itu berlangsung dalam tiga tahun terahhir.

\section{Model Komunikasi untuk Membangun Kapasitas Kewirausahaan dan Kesiapan Pedagang Menghadapi Revitalisasi}

Pada Tabel 4 dapat dilihat rendahnya tingkat kesiapan pedagang untuk berubah terkait dengan revitalisasi. Pedagang memiliki optimisme terhadap revitalisasi, tetapi tingkat partisipasinya dalam revitalisasi sangat rendah. Dalam penelitian ini 
Tabel 4. Skor dan Korelasi antar Peubah-peubah Terkait Komunikasi dalam Membangun Kesiapan Pedagang Menghadapi Revitalisasi

\begin{tabular}{|c|c|c|c|c|c|c|c|c|c|c|}
\hline & Mean & SD & $\mathrm{X1}$ & $\mathrm{X} 2$ & $\mathrm{X3}$ & $\mathrm{X4}$ & $\mathrm{X5}$ & Y1 & Y2 & Y3 \\
\hline $\mathrm{X} 1$ & 65,0 & 15,8 & 1,00 & $-0,078$ & $0,27 * *$ & $0,22 * *$ & $0,26^{* *}$ & $0,18^{* *}$ & $0,37 * *$ & $0,22 * *$ \\
\hline $\mathrm{X} 2$ & 45,3 & 18,2 & $-0,08$ & 1,00 & $0,41 * *$ & $0,47 * *$ & $0,30 * *$ & $0,49 * *$ & $0,17 * *$ & $0,43 * *$ \\
\hline $\mathrm{X} 3$ & 53,6 & 23,3 & $0,27 * *$ & $0,41^{* *}$ & 1,00 & $0,90 * *$ & $0,44 * *$ & $0,69 * *$ & $0,31 * *$ & $0,33 * *$ \\
\hline $\mathrm{X} 4$ & 43,3 & 18,2 & $0,22 * *$ & $0,47 * *$ & $0,90 * *$ & 1,00 & $0,53 * *$ & $0,77 * *$ & $0,38 * *$ & $0,38 * *$ \\
\hline $\mathrm{X} 5$ & 35,2 & 9,0 & $0,26^{* *}$ & $0,30 * *$ & $0,44 * *$ & $0,53 * *$ & 1,00 & $0,50 * *$ & $0,53 * *$ & $0,40 * *$ \\
\hline Y1 & 50,9 & 19,1 & $0,18^{* *}$ & $0,49 * *$ & $0,69^{* *}$ & $0,77 * *$ & $0,50 * *$ & 1,00 & $0,43 * *$ & $0,41 * *$ \\
\hline Y2 & 54,8 & 20,3 & $0,37 * *$ & $0,17 * *$ & $0,31 * *$ & $0,38 * *$ & $0,53 * *$ & $0,43 * *$ & 1,00 & $0,46^{* *}$ \\
\hline $\mathrm{Y} 3$ & 32,5 & 12,1 & $0,22 * *$ & $0,435^{* *}$ & $0,33 * *$ & $0,38 * *$ & $0,39 * *$ & $0,41 * *$ & $0,46^{* *}$ & 1,00 \\
\hline 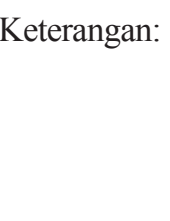 & & $\begin{array}{l}0-25 \\
\text { Karal } \\
\text { Kom } \\
\text { Kapa }\end{array}$ & $\begin{array}{l}\text { pada } 0,01 \\
\text { angat rend } \\
\text { istik Peda } \\
\text { rasi Partisi } \\
\text { s Kewirau }\end{array}$ & $\begin{array}{l}\text { h; } 26-50 \\
\text { ang; } \\
\text { atif; } \\
\text { ahaan; }\end{array}$ & $\begin{array}{l}\text { Rendah; 51- } \\
\text { X2=Kredibi } \\
\text { X5 = Dukun } \\
\text { Y3= Kesiap }\end{array}$ & $\begin{array}{l}75=\text { Seda } \\
\text { litas Peng } \\
\text { gan Lingk } \\
\text { an Beruba }\end{array}$ & $\begin{array}{l}; 76-100 \\
\text { ola Pasar; } \\
\text { ggan; }\end{array}$ & $\begin{array}{l}\text { Tinggi } \\
\mathrm{X} 3=\text { Pes } \\
\mathrm{Y} 1=\text { Kua }\end{array}$ & $\begin{array}{l}\text { Revitali } \\
\text { tas Kom }\end{array}$ & \\
\hline
\end{tabular}

partisipasi diukur dari kepatuhan pedagang membayar iuran hingga mengikuti kegiatan pertemuan yang membahas soal revitalisasi. Pedagang memenuhi kewajiban sebagai pengguna pasar seperti membayar iuran. Itupun seringkali pedagang mengeluhkan soal ketidak seimbangan antara iuran yang dibayar dan kondisi pasar yang dijanjikan. "Dimana-mana masih kelihatan kotor. Bahkan untuk keamanan kami juga meminta tolong petugas Koramil," kata seorang pedagang.

Dalam hal partisipasi dalam pertemuan, menurut informasi yang diberikan oleh seorang pedagang, bila permasalahan yang diangkat serius, seperti kenaikan iuran, banyak pedagang hadir. Namun saat tentang penjelasan revitalisasi banyak pedagang yang mewakilkannya ke orang lain lain atau paguyuban pasar.

Hasil uji kesesuaian model menunjukkan bahwa hybrid model yang diperoleh (Gambar 1) adalah fit. Indikator Goodness of Fit juga bisa dilihat dari rasio perbandingan antara nilai Chi-Square dan degree of freedom $\chi^{2} / \mathrm{df}$. Rasio $\chi^{2} / \mathrm{df}$ dalam model tersebut adalah $840 / 467=1.8$ atau kurang dari 2 yang menurut Carmines dan McIver (1981) adalah baik.

Nilai Root Mean Square Error of Approximation (RMSEA) model pada Gambar 2 sebesar 0.0773 atau berada dalam kisaran good fit $(0.05 \leq \mathrm{RMESEA} \leq 0.08)$. Demikian pula dengan nilai Goodness of Fit Index (GFI) sebesar 0.99 atau lebih besar dari 0.09 menunjukkan bahwa model tersebut adalah good fit. Karena itu, model pada Gambar 1 dapat digeneralisasikan.
Gambar 1 memperlihatkanbahwakarakteristik pedagang, kredibilitas sumber pesan, terpaan pesan perubahan, komunikasi partisipasif, dan dukungan lingkungan mempengaruhi kualitas komunikasi, kapasitas kewirausahaan, dan kesiapan untuk berubah. Bila dibuat persamaannya maka model persamaannya adalh sebagai berikut:

$$
\begin{gathered}
\mathrm{Y} 1=0.050 * \mathrm{X} 1+0.44 * \mathrm{X} 2+0.25 * \mathrm{X} 3+ \\
0.18 * \mathrm{X} 4+0.16^{*} \mathrm{X} 5 \ldots \ldots \ldots \ldots \ldots(1) \\
\mathrm{Y} 2=0.61 * \mathrm{Y} 1+0.46 * \mathrm{X} 1-0.15 * \mathrm{X} 2-0.13 * \mathrm{X} 3 \\
-0.091 * \mathrm{X} 4+0.46 * \mathrm{X} 5 \ldots \ldots(2) \\
\mathrm{Y} 3=-0.081 * \mathrm{Y} 1+0.20 * \mathrm{Y} 2+0.054 * \mathrm{X} 1+ \\
0.43 * \mathrm{X} 2-0.097 * \mathrm{X} 3+0.042 * \mathrm{X} 4+0.28 * \mathrm{X} 5 \ldots \ldots(3)
\end{gathered}
$$

Dari persamaan 1 diperoleh informasi bahwa nilai $\mathrm{R}^{2}=0.84$ yang menunjukkan bahwa pengaruh peubah karakteristik pedagang (X1), kredibilitas pengelola pasar (X2), pesan-pesan komunikasi perubahan (X3), komunikasi partisipatif (X4), dan dukungan lingkungan (X5) terhadap kualitas komunikasi (Y1) sebesar $84 \%$ dan sisanya (26\%) dipengaruhi oleh faktor-faktor lain yang dalam penelitian ini tidak diteliti.

Hasil penelitian ini menunjukkan bahwa secara langsung karakteristik pedagang, kredibilitas pengelola pasar, pesan-pesan perubahan, komunikasi partisipatif dan dukungan lingkungan berpengaruh positif terhadap kualitas komunikasi. Ini menunjukkan bahwa untuk membangun komunikasi yang berkualitas diperlukan penguatan pedagang. Semakin tinggi pendidikan pedagang, omset, tingkat keuntungan 
dan modal untuk berdagang membutuhkan kualitas komunikasi yang semakin tinggi atau informasi yang relevan, jelas, akurat dan lengkap.

Komunikasi yang berkualitas membutuhkan pengelola pasar yang kredibel, pesan-pesan perubahan yangintensifdenganmodelkomunikasiyang partisipatif serta dukungan lingkungan. Hal ini menunjukkan bahwa dalam komunikasi untuk membangun kesiapan pedagang menghadapi revitalisasi, semakin tingi kredibilitas pedagang pasar, semakin tinggi kualitas komunikasi.

Dari persamaan 2 diperoleh informasi $\mathrm{R}^{2}$ $=0.33$ yang menunjukkan bahwa pengaruh peubah $\mathrm{X} 1, \mathrm{X} 2, \mathrm{X} 3, \mathrm{X} 4, \mathrm{X} 5$, dan Y1 terhadap kapasitas kewirausahaan (Y2) secara simultan sebesar 33\% sedangkan sisa (67\%) dipengaruhi oleh faktor-faktor lain yang tidak diteliti. Ini memberikan gembaran rendahnya pengaruh-pengaruh peubah tersebut terhadap kapasitas kewirausahaan. Penguatan kredibilitas pengelola pasar, pesan perubahan dan komunikasi partisipatif berpengaruhjustrumenurunkan kapasitas kewirausahaan pedagang. Namun demikian, pengaruhnya tidak besar dibandingkan dengan peubah-peubah karakteristik pedagang, dukungan lingkungan dan kualitas komunikasi. Dengan kata lain, jika pengelola pasar memperkuat komunikasi yang berkualitas, mereka dapat meningkatkan kapasitas kewirausahaan secara maksimal untuk mewujudkan kinerja usahanya secara efektif.

Pengaruh peubah X1, X2, X3, X4, X5, Y1, dan Y2 terhadap Y3 (Kesiapan Pedagang Berubah atau Siap Menghadapi Revitalisasi) signifikan pada $\mathrm{R}^{2}=0.61$ atau sebesar $61 \%$. Dengan demikian untuk membangun kesiapan pedagang dalam menghadapi perubahan, tindakan komunikasi membutuhkan komunikasi partisipatif dengan penyampai pesan yang kredibel, pesan perubahan, dukungan lingkungan lingkungan, komunikasi yang berkualitas, dan kapasitas kewirausahaan. Kredibilitas pengelola pasar memberikan kontribusi terhadap kapasitas kewirausahaan. Secara langsung, penguatan kredibilitas pengelola menurunkan kapasitas kewirausahaan, namun secara tidak langsung yakni melalui penguatan komunikasi yang mampu memberikan informasi relevan, jelas, akurat dan lengkap, kredibilitas pengelola dapat memperkuat kewirausahaan. Dengan demikian, secara keseluruhan, kredibilitas pengelola pesan dapat memperkuat kapasitas kewirausahaan.

Hal ini menunjukkan bahwa upaya meningkatkan kapasitas kewirausahaan pedagang pasar melalui peningkatan kredibilitas (kepercayaan pedagang terhadap pengelola pasar, keahlian pengelola pasar, dan daya tarik pengelola pasar) meningkatkan kapasitas kewirausahaan pedagang pasar. Namun syaratnya, dalam berkomunikasi pengelola pasar harus memberikan informasi yang relevan, jelas, akurat dan lengkap. Tanpa komunikasi yang berkualitas, meningkatkan kredibilitas justru bisa menurunkan kapasitas kewirausahaan pedagang pasar.

Pesan-pesan tentang risiko kurang disampaikan oleh pengelola pasar. Pesan risiko ini misalnya kemungkinan yang terjadi bila revitalisasi gagal dilaksanakan, termasuk dampak negatif yang terjadi karena revitalisasi pasar. Hal ini memunculkan kesan pengelola pasar sengaja menyembunikan informasi tentang revitalisasi. "Yang disampaikan hanya dampak positifnya. Dampak negatif setelah pasar direvitalisasi tidak dijelaskan," kata Pedagang Narasumber I. Padahal, menurut Miller dan Monge (1985), selama proses perubahan, orang cenderung lebih menyukai pesan atau informasi, termasuk informasi yang negatif.

Hasil penelitian ini memberikan gambaran bahwa pengaruh pesan sangat menonjol dalam membangun kesiapan perubahan. Hasil penelitian ini memperkuat hasil penelitian Armenakis et al., (1993) yang menekankan pentingnya tindakan yang diperlukan untuk menciptakan kesiapan untuk perubahan. Yang pertama adalah mengkomunikasikan pesan yang jelas tentang perbedaan antara status quo dan status perubahan akhir yang diinginkan.

Tindakan kedua adalah membangun kepercayaan bahwa mereka memiliki pengetahuan, keterampilan dan kemampuan yang dibutuhkan untuk memenuhi persyaratan yang dibutuhkan untuk mengatasi perbedaan tadi. Dimensi kedua hasil penelitian Armenakis et al., (1993) tersebut merupakan dimensi dari kapasitas kewirausahaan yang digunakan dalam penelitian ini. Dengan kata lain, untuk membangun kesiapan perubahan, selain komunikasi juga dibutuhkan tindakan memperkuat kapasitas kewirausahaan.

Penelitian yang dilakukan Crowley dan Hoyer (1994) menunjukkan bahwa penggunaan pesan yang membujuk disertai argumentasi atau dampak negatifnya, pertama, menghasilkan tanggapan yang diharapkan oleh pembuat atau penyampai pesannya. Menurut mereka, pesan dua sisi biasanya menunjukkan 


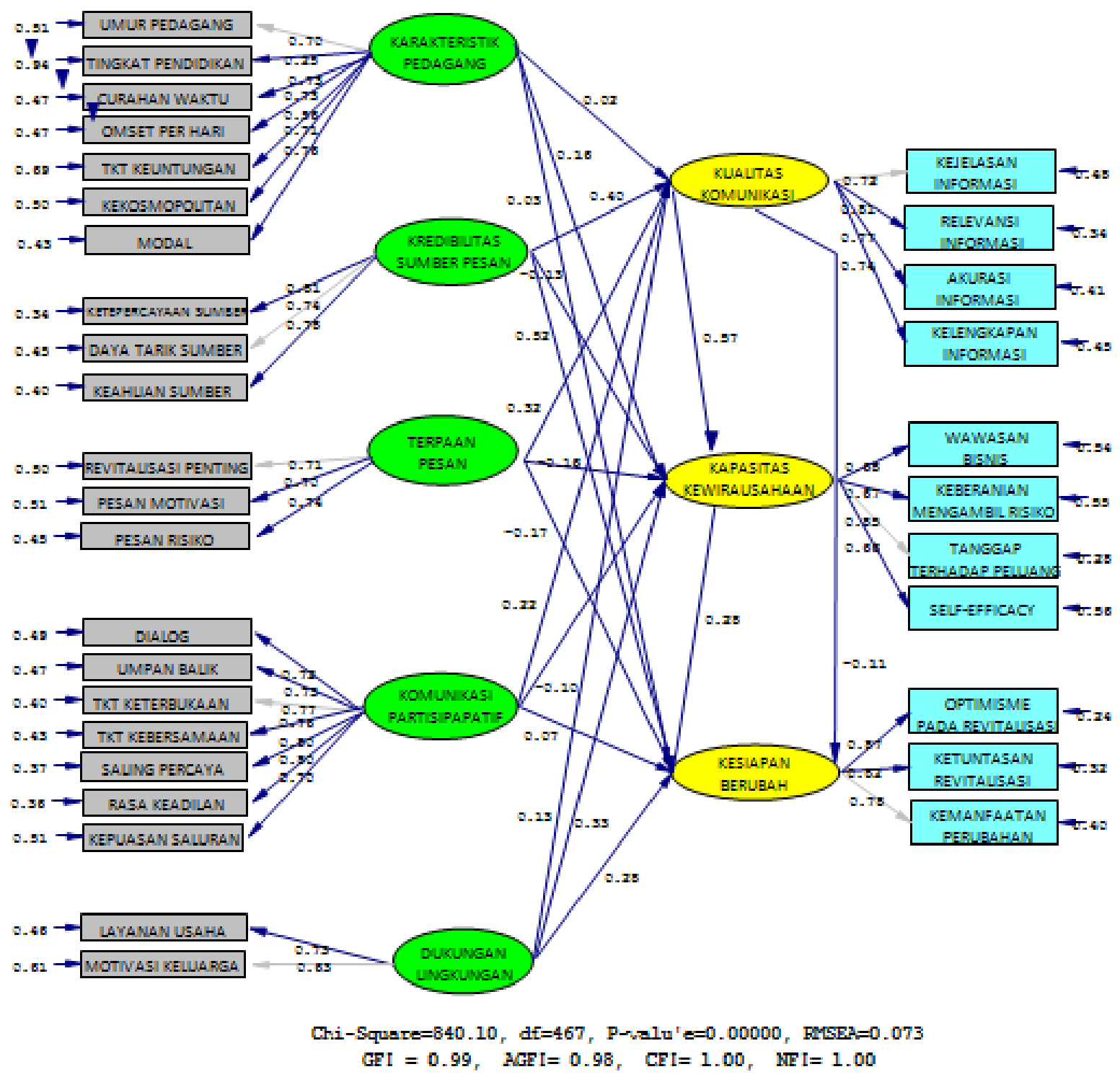

Gambar 1. Model Komunikasi Untuk Membangun Kesiapan Pedagang Pasar Menghadapi Revitalisasi

kebaruan, menarik, kredibel dan mendorong audience untuk memperhatikan dan memberikan motivasi. Kedua, membuat pesan menjadi lebih kredibel termasuk dalam situasi ketika penerima pesan mendapatkan informasi negatif dari pihak lain.

Dari sini diperoleh gambaran bahwa apabila pengelola pasar menyampaikan informasi negatif tentang dampak revitalisasi misalnya, pedagang mempersepsikan pengelola pasar sebagai orang yang kredibel dan menguasai masalah revitalisasi. Ini karena pedagang menganggap bila pengelola menyampaikan dampak negatif setelah revitalisasi, pedagang menganggap pengelola menguasai masalah. Ini sekaligus menunjukkan keahlian penyampai pesan yang merupakan faktor penting dalam meningkatkan kredibilitas sumber pesan.

Pasar merupakan fasilitas publik yang dalam penyediaannya membutuhkan adanya keputusan publik. Karena keputusan publik sangat terkait dengan proses berdemokrasi, maka pengembangan komunikasi pembangunan dalam penyediaan prasarana pasar hendaknya juga memperhatikan tipologi berdemokrasi yang ada di kawasan pasar yang dibangun tersebut.

Hasil penelitian menunjukkan bahwa komunikasi partisipatif memberikan dampak positif terhadap kualitas komunikasi. Dengan kata lain, dengan komunikasi pertisipatif, pengelola mampu memberikan informasi yang jelas, relevan, 
akurat dan lengkap. Komunikasi partisipatif juga memberikan dampak yang positif terhadap kesiapan pedagang berkaitan dengan revitalisasi. Akan tetapi, komunikasi partisipatif memberikan dampak negatif pada kapasitas kewirausahaan sehingga menurunkan dampak positifnya terhadap kesiapan pedagang dalam kaitannya dengan revitalisasi.

Dari model diatas dapat dilihat bahwa pengembangan kapasitas kewirausahaan merupakan faktor utama pembentuk kesiapan pedagang untuk berubah. Dukungan lingkungan penting, namun dukungan tersebut baru memberikan kontribusi positif bagi pembangunan kesiapan pedagang untuk berubah bila mampu meningkatkan kapasitas kewirausahaan. Ini karena dukungan lingkungan justru memberikan pengaruh yang arahnya negatif kepada kesiapan pedagang untuk berubah.

\section{Kesimpulan}

Proses komunikasi pengelola dan pedagang dimulaidarirencana pengelolapasaryang merevitalisasi pasar. Penyebaranluasan informasi tentang rencana revitalisasi dilakukan dengan menggunakan media spanduk, papan pengumuman, dan selebaran. Selain itu dilakukan dialog pengelola dan pedagang. Dialog berlangsung dua arah namun kurang memuaskan. Umpan balik selama dialog juga rendah. Demikian rasa saling percaya antara pengelola dan pedagang juga rendah. Komunikasi partisipatif yang diharapkan dapat membangun kesiapan pedagang pada realitasnya masih lemah. Akibatnya, tingkat kesiapan pedagang untuk berubah terkait dengan revitalisasi masih rendah.

Selain komunikasi partisipatif, tingkat kesiapan pedagang dalam kaitannya dengan revitalisasi juga dipengaruhi oleh karakteristik pedagang, kredibilitas pengelola pasar, pesan-pesan yang disampaikan selama proses revitalisasi dan dukungan lingkungan. Realitasnya, kredibilitas pengelola, pesan-pesan dan komunikasi partisipatif rendah sehingga kualitas komunikasi yang dihasilkan juga rendah. Hal ini ditunjukkan rendahnya relevansi, kejelasan, keakuratan dan kelengkapan informasi yang disampaikan.

Pesan-pesan yang disampaikan pengelola pasar kepada pedagang kurang tajam. Hal ini dapat dilihat dari kurang disampaikannya pesan-pesan tentang pentingnya revitalisasi, motivasi, pernyataan bahwa revitalisasi merupakan program yang tepat dan kurang disampaikannya pesan-pesan tentang risiko revitalisasi.

Komunikasi yang dilakukan pengelola pasar juga mempengaruhi kapasitas kewirausahaan pedagang. Tanggapan pedagang terhadap komunikasi tersebut berbeda menurut tingkatan masing-masing karakteristik. Pedagang yang berumur lebih tinggi cenderung memiliki kapasitas kewirausahaan yang lebih rendah karena semakin tinggi umur pedagang makin rendah keberaniannya dalam menanggung risiko dan kurang tanggap terhadap peluang.

Namun demikian, pengaruh komunikasi lemah bila dukungan lingkungan pedagang lemah. Ini berarti untukmeningkatkankapasitas kewirausahaan diperlukan penguatan terhadap dukungan lingkungan. Dukungan lingkungan berupa layanan usaha dan dukungan keluarga berperan penting dalam meningkatkan kapasitas kewirausahaan pedagang. Di sisi lain, kapasitas kewirausahaan berperan penting dalam membangun kesiapan pedagang menghadapi revitalisasi. Karena itu, untuk membangun kesiapan pedagang, hal utama yang perlu dilakukan adalah membangun kapasitas kewirausahaan pedagang. Kekurang berhasilan membangun kapasitas kewirausahaan menghasilkan dampak ketidaksiapan pedagang.

Berdasarkan temuan-temuan tersebut, model komunikasi yang dinilai tepat adalah melibatkan pengelola pasar sebagai sumber pesan yang kredibel, dengan muatan pesan tentang manfaat dan risiko revitalisasi ternyata efektif bila melalui pengembangan motivasi pedagang untuk berubah, dan media yang memungkinkan terjadi tanggapan langsung dari pelaku komunikasi.

Berdasarkan model itu, disampaikan beberapa saran antara lain bahwa dalam melakukan komunikasi, pengelola perlu memahami karakteristik pedagang. Karena tanggapan pedagang yang berbeda terhadap komunikasi yang dilakukan, dalam komunikasi pengelola perlu menentukan segmen tertentu dari pedagang yang memberikan tanggapan positif. Dalam hal ini adalah memilih pedagang berumur lebih muda sebagai khalayak sasaran. Karena merekalah yang diharapkan menularkan kesiapannya kepada yang lain.

Penguatan kapasitas kewirausahaan dapat dilakukan dengan memperkuat kualitas komunikasi melalui penguatan kredibilitas pengelola, pesan-pesan revitalisasi, komunikasi paristisipatif dan dukungan lingkungan antara lain berupa layanan usaha. Selain pesan motivasi, juga perlu dilakukan penguatan terhadap pesan-pesan tentang risiko dari revitalisasi. 
Pesan-pesan tersebut disampaikan oleh sumber informasi yang kredibel.

Penguatan kredibilitas pengelola pasar sebagai sumber pesan perlu dilakukan dengan memperkuat komunikasi internal sehingga koordinasi antara sumber pesan dalam dialog informal sejalan dengan sumber pesan dalam dialog informal. Untuk membangun dialog dengan pedagang, pengelola bisa memanfaatkan pengelola yang telah akrab dan memiliki daya tarik di kalangan pedagang. Hal ini bisa dilakukan setelah sumber pesan tersebut telah memiliki keahlian yang diharapkan diperoleh dari komunikasi internal yang dibangun pengelola.

\section{Daftar Pustaka}

Alfianita E, Wijaya AF, Siswidiyanto. 2015, Revitalisasi Pasar Tradisional dalam Perspektif Good Governance: Studi di Pasar Tumpang Kabupaten Malang. Jurnal Administrasi Publik (JAP), 3(5) : 758-762

Armenakis AA, Bedeian AG. 1999. Organizational change: A review of theory and research in the 1990s. Journal of Management, 25(1) : 293-315.

Armenakis AA, Harris SG, Mossholder KW. 1993. Creating readiness for organizational change. Human Relations; Thousand Oaks, 46(6) : 681697.

Arnstein SR. 1969. A ladder of citizen participation. Journal of the American Institute of Social Planners $4: 216-224$

AyuningsasiAAK.2010.Analisis Pendapatan pedagang Sebelum dan Sesudah Program Revitalisasi Pasar Tradisional di Kota Denpasar (Studi Kasus Pasar Sudha Merta DesaSidakarya. Jurnal Piramida, $7(1)$.

Bandura A. 1986. Social foundations of thought and action: a social cognitive theory. Englewood Cliffs, N.J.: Prentice-Hall.

Barringer BR, Bludorn AC. 1999. The Relationship Between corporate Entrepreneurship and Strategic Management. Strategic Management Journal, 20(5) : $421-444$

Baser H, Morgan P. 2008. Capacity, Change and Performance Study Report. (ECDPM Discussion Paper 59B). Maastricht: ECDPM.

Baxter LA, Montgomery BM. 1996. Relating: Dialogues and dialectics. New York (US): Guilford Press.
Becker B, Gerhard B. 1996. The Impact Resources Management on Organizational Performance: Progress and Perspectives. Academy of Management Journal, 39(4) : 779-801

Berger CR, Calabrese RJ. 1975. Some explorations in initial interaction and beyond: Toward a developmental theory of interpersonal communication. Human Communication Research 1: 99-112.

Brown L, LaFond A, Macintyre K. 2001. Measuring capacity building. Measure Evaluation. Carolina Population Center, University of North Carolina at Chapel Hill.

Butler JK Jr. 1991. Towards understanding and measuring conditions of trust: Evolution of conditions for trust inventory. Journal of Management 17: 643-63.

Carmines EG, McIver JP. 1981. Analyzing Models with Unobservedd Variable. Dalam Bohrnstedt GW and Borgatta EF (editors). Social Measurement: Current Issues. Beverly Hills, CA Sage

CooperAC, Folta TB, dan Woo C. 1995. Entrepreneurial Information Search. Journal of Business Venturing 10: $107-20$

Crowley AE, Hoyer WD. 1994. An integrative framework for understanding two-side persuasion. Journal of Consumer Research 20: 561-574.

DiFonzo N, Bordia P. 1998. A tale of two corporations: Managing uncertainty during organizational change. Human Resource Management 37: 295303.

Drucker PF. 1985. Innovation and Entrepreneurship. New York: Harper and Row Publishers.

Gist ME, Mitchell TR. 1992. Self-Efficacy - a Theoretical-Analysis of Its Determinants and Malleability. Academy of Management Review 17:183-211.

Halim RE, Ismaeni F. 2007. Analisis Pembentukan Ketertarikan Terhadap Ritel Agenda Riset Bagi Revitalisasi Pasar Tradisional di Indonesia. Manajemen Usahawan Indonesia, 36 (12): 8- 18.

Havelock RG. 1971. The Utilization of Educational Research and Development. British Journal of Educational Technology 2(2).

Henry C, Hill F, Leitch C. 2005. Entrepreneurship education and training: canentrepreneurship be taught? Education and Training 47(2) : 98-111.

Jianakoplos A, Bernasek A. 1998. Are women more risk averse? Economic Inquiry 36(4) : 620-631. 
Klein PG, Cook ML. 2006. T.W. Schultz and the Human-Capital Approach to Entrepreneurship. Review of Agricultural Economics, 28(3): 344350.

Kramer MW. 1999. Motivation to reduce uncertainty. Management Communication Quarterly 13(2) : 305-316.

Lumpkin GT, Dess GG. 1996. Clarifying the entrepreneurial orientation construct and linking it to performance. Academy of Management Review, 21(1):135-172.

McGrath RG, MacMillan I. 2000. The Entrepreneurial Mindset. Cambridge, Mass.: Harvard Business School Press.

Mc.Chelland D. 1998. Memacu Masyarakat Berprestasi. Jakarta (ID): Intermedia.

McDivitt JA, Zimicki S, dan Hornik RC. 1997. Explaining the impact of a communication campaign to change vaccination knowledge and coverage in the Philippines. Health Communication $9(2): 95-118$.

Meredith GG, Nelson RE, dan Neck PA. 1996. Kewirausahaan: Teori dan Praktek. Terjemahan. Andre Asparasayogi. Jakarta (ID): LPPM dan PT Pustaka Binaman Pressindo.

Miller KI, Monge PR. 1985. The influence of social information on employee anxiety about organizational change. Human Communication Research, $11: 365-386$.

Milliken FJ. 1987. Three types of perceived uncertainty about the environment: state, effect, and response uncertainty. Academy of Management Review, 12(1) : 133-145.

Morgen W. 2010. Time for Change: The New Role of CFO. Corporate Finance Review, 14(5) : 26-34.

Mubyarto. 1985. Peluang Kerja dan Berusaha di Pedesaan. Yogyakarta (ID): BPEE.

Muhidin SA. 2011. Dasar-dasar Metode Statistika untuk Penelitian. Bandung (ID): Pustaka Setia.

Nastase P, Stoica D. 2010. Anew Business DimensionBusiness Analytics. Accounting and Management Information Systems, 9(4) : 603-618.

Politis D. 2005. The process of entrepreneurial learning: A conceptual framework. Entrepreneurship Theory and Practice, 29(3) : 399-424.

Prastyawan A, Suryono A, Soeaidy MS, dan Muluk K. 2015. Revitalization of Traditional Markets into a Modern Market in the Perspective of Local Governance Theory: Studies on Revitalization
Wonokromo Market in Surabaya. IOSR Journal of Humanities and Social Science (IOSR-JHSS), 20(9) : 01-06

Putta SS. 2014. Improving Entrepreneur's Management Skills through Entrepreneurship Training. Journal of Commerce and Management Thought, 5(3) : 459-474.

Rae D. 2006. Entrepreneurial learning: A conceptual framework for technology-based enterprise. Technology Analysis and Strategic Management, 18(1) : 39-56.

Rahayuningrum N, Widayanti T. 2008. Kajian Dampak Ekonomi Kerberadaan Hypermarket terhadap Ritel/Pasar Tradisional. Bulletin Ilmiah Litbang Perdagangan, 2(1) : 3-17.

Rhodes SR. 1983. Age-related differences in work attitudes and behavior: A review and conceptual analysis. Psychological Bulletin, 93 : 328-367.

Rogers EM. 1976. Communication and development: The passing of the dominant paradigm. Communication Research, $3: 213-240$.

Rogers EM. 2003. Diffusion of innovations (5th ed). New York (US): Free Press.

Santosa A, Indroyono P. 2011. Pedagang Pasar Tradisional Terancam. Jurnal Ekonomi Rakyat, No. 108/13.

Sapar, Lumintang RWE, Susanto D. 2006. Faktor-faktor yang Berkaitan dengan Perilaku Kewirusahaan Pedagang Kakilima: Kasus Pedagang Kakilima Pemakai Gerobak Usaha Makanan Di Kota Bogor. Bogor (ID): Jurnal Penyuluhan, 2(2) : 161168.

Sumarti T, Rokhani, Falatehan SF. 2017. Strategi Pemberdayaan Petani Muda Kopi Wirausaha di Kabupaten Simalungun. Bogor (ID): Jurnal Penyuluhan, 13(1) : 31-39.

Tjokroamidjojo B. 2004. Reformasi Nasional Penyelenggaraan Good Governance dan Perwujudan Masyarakat Madani. Jakarta (ID): LAN.

Rufaidah P. 2008. Peran Teknologi Komunikasi Dalam Rantai Nilai Pedagang Di Pasar Tradisional. Jurnal Sosioteknologi, 7(14).

Senjaya S, Pekerti A. 2010. Servant leadership as antecedent of trust in organizations. Leadership \& Organization Development Journal, 31(7) : 643663.

Simanjuntak P. 1985. Pengantar Ekonomi Sumber Daya Manusia. Jakarta (ID): FE UI. 
Smith AJ, Collins LA, dan Hannon PD. 2006. Embedding new entrepreneurship programmes in UK higher education institutions, challenges and considerations. Education and Training, 48(8/9) : 555-567.

Sumardjo. 1999. Transformasi Model Penyuluhan Pertanian Menuju Pengembanga Kemandirian Petani Kasus di Provinsi Jawa Barat. [Disertasi]. Bogor (ID): Institut Pertanian Bogor.

Suryadarma D, Poesoro A, Budiyati S, Akhmadi, dan Rosfadhila M. 2007. Dampak Supermarket terhadap Pasar dan Pedagang Ritel Tradisional di Daerah Perkotaan di Indonesia. Laporan Penelitian SMERU.

Tarigan R. 2005. Ekonomi Regional: Teori dan Aplikasi. Jakarta (ID): PT Bumi Aksara.

Vaizey J. 1992. Pendidikan di Negara-negara Maju, Terjemahan oleh Murtini, LP. Majalah Prisma, LP3ES No.2 Tahun X.

Waisbord S. 2008. The institutional challenges of participatory communication in international aid. Social Identities, 14(4) : 505-522.

Weber M. 1964. The Theory of Social and Economic Organization. Dalam AM Henderson \&T Parsons (Ed.). York (US): Free Press.

Wijayanto SH. 2008. Structural Equation Modeling dengan LISREL 8.8: Konsep \& Tutorial. Yogyakarta (ID): Graha ilmu.

Willems S, Baumert K. 2003. Institutional Capacity and Climate Actions, COM/ENV/EPOC/IEA/SLT 5, OECD/IEA, Paris.

Wright M, Robbie K, dan Ennew C. 1997. Venture Capitalists and Serial Entrepreneurs. Journal of Business Venturing, 12(3) : 227-249.

Xiao JJ, Alhabeeb MJ, Hong GS, dan Haynes GW. 2001. Attitude toward risk and risk-taking behaviour of business-owning families. The Journal of Consumer Affairs, 35(2) : 307- 325.

Zainura U, Kusnadi N, Burhanuddin. 2016. Perilaku Kewirausahaan Petani Kopi Arabika Gayo di Kabupaten Bener Meriah Provinsi Aceh. Bogor (ID): Jurnal Penyuluhan, 12(2) : 126-143.

Zang W, Hong S. 2015. Perceived Discrimination and Psychological Distress Among Asian Americans: Does Education Matter?. Journal of Immigrant and Minority Health, 15(5) : 932-43.

Zhao H, Seibert SE, Hills GE. 2005. The mediating role of self-efficacy in the development of entrepreneurial intentions. Journal of Applied
Psychology, 90 : 1265-1272.

Zimmerer TW, Scarborough NM. 2002. Pengantar Kewirausahaan Dan Manajemen Bisnis Kecil (Edisi Bahasa Indonesia) Jakarta. Jakarta (ID): PT. Rineka Cipta. 